Boletín de la Sociedad Geológica Mexicana

Volumen 60, NúM. 2, 2008, P. 187-201

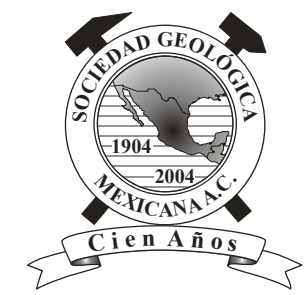

\title{
Mechanical instability quantification of slopes at Cofre de Perote volcano, eastern Mexico
}

\author{
Rodolfo Díaz Castellón ${ }^{1, *}$, Gerardo Carrasco Núñez², Alfonso Álvarez-Manilla Aceves ${ }^{1,3}$ \\ 'Posgrado en Ciencias de la Tierra Centro de Geociencias Universidad Nacional Autónoma de México, \\ Campus Juriquilla, Querétaro, Qro. 76230 \\ ${ }^{2}$ Centro de Geociencias, Universidad Nacional Autónoma de México, \\ Campus Juriquilla, Querétaro, Qro. 76230. \\ ${ }^{3}$ Dirección de Estudios de Posgrado de la Facultad de Ingeniería, Universidad Autónoma de Querétaro, \\ Ciudad Universitaria, Cerro de las Campanas s/n, Querétaro, Qro. 76010 \\ *rdiaz@geociencias.unam.mx.
}

\begin{abstract}
Cofre de Perote (CP) volcano is located at the eastern end of the Trans-Mexican Volcanic Belt (TMVB) at 19³0' Lat N, 97 10' Long W. At a height of 4,282 m.a.s.1, it comprises one of the most massive structures within the Citlaltépetl - Cofre de Perote volcanic range (CCPVR), which constitutes an important physiographic barrier that separates the central altiplano, also known as Serdán Oriental, from the coastal plains of the Gulf of Mexico. This massive structure has repeatedly collapsed, and at least two of the collapse events occurred long after activity ceased, suggesting that even extinct volcanoes may pose an important hazard to nearby populated areas. In the present work, volcanic instability is approached through both quantitative and descriptive methods that include combined numerical analysis of limit equilibrium, calculated with Bishop's modified method, and finite element analysis. The combined techniques were applied after attaining mechanical parameters in the laboratory, the field and through careful geological observations in order to obtain a model that approaches structural conditions prior to the destruction of the volcano

Reconstruction of the ancient volcano was used to propose an instability model for the modern summit, where maximum stress/ strain relationships before failure were determined for the reconstructed section and actual volcano summit. Results obtained from these models indicate that the volcanic edifice is still unstable, could experience failure in the near future, and should be considered for future hazard assessment.
\end{abstract}

Key words: volcanic instability, Cofre de Perote, quantitative assessment, inactive volcanoes.

Resumen

El volcán Cofre de Perote (4,282 m.s.n.m); está localizado $19^{\circ} 30^{\prime} \mathrm{N} ; 97^{\circ} 10^{\prime} \mathrm{W}, 24 \mathrm{~km} \mathrm{WSW}$ de la Ciudad de Xalapa. Comprende una El volcán Cofre de Perote (4,282 m.s.n.m); está localizado 19³0' N; 97 10' W, $24 \mathrm{~km}$ WSW de la Ciudad de Xalapa. Comprende una de las estructuras más masivas de la cordillera volcánica Citlaltépetl-Cofre de Perote (CCPVR) en el centro-oriente de México: Esta cordillera representa una importante barrera fisiográfica que separa el altiplano central, también denominado como Cuenca del Serdán Oriental, de las planicies costeras del Golfo de México, en el extremo oriental del Cinturón Volcánico Trans-Mexicano (TMVB). Esta estructura ha colapsado repetidamente y, en al menos dos ocasiones, ha sido mucho después del cese de su actividad, sugiriendo que incluso volcanes extintos pueden representar peligros importantes a las poblaciones cercanas. El presente trabajo analiza la inestabilidad volcánica por medio de una combinación de métodos cuantitativos y descriptivos, mediante el método de equilibrio límite a través del modelo modificado de Bishop, y modelación por medio de análisis de elementos finitos. Las técnicas combinadas fueron aplicadas en forma posterior a la obtención de parámetros mecánicos en el laboratorio y en el campo, en combinación con cuidadosas observaciones geológicas que dieron como resultado un modelo que aproxima las condiciones de estabilidad estructural previa a la destrucción del volcán. Estas observaciones fueron utilizadas para recrear la destrucción de la cima con el objeto de determinar las condiciones de estabilidad actual, y en donde ambas técnicas combinadas ayudan a determinar las condiciones de 
esfuerzo-deformación previas a la falla. Los resultados obtenidos de esta modelación indican que el edificio volcánico continúa siendo inestable y que un evento recurrente debe ser considerado en la evaluación de peligros

Palabras clave: Inestabilidad volcánica, Cofre de Perote, evaluación cuantitativa, volcanes inactivos.

\section{Introduction}

Quantifiable determination of mechanical instability conditions was until just a few years ago a field exclusive to civil engineering and other disciplines associated with construction and infrastructure works (i.e. Duncan, 1996; Yu et al., 1998). Studies of the mechanical characteristics of large sectors of single volcanoes have been performed only very recently and are, for the most part, mainly descriptive and/or combined with structural geology measurements (i.e. Tibaldi et al., 2003), which might be because of the increased need in computer power required for slope stability quantification. However, advances in computer technology along with continued breakthroughs in the understanding of rock mass behavior have helped simulate complex scenarios with a high degree of certainty at a low cost. Studies of mechanical instability of a complex scenario like that found on a volcano slope imply considerations regarding the hydraulic conductivity, coupled interface between contiguous strata, and combined joint behavior of the volcanic massif.

Furthermore, most of the works dealing with volcano slope instability focus on the destruction of edifices linked to the presence of a magmatic component (i.e. Siebert et al., 1987), leaving the structural behavior of inactive or dormant volcanoes practically unexplored. There are several weakening factors that have to be considered when attempting an evaluation of the structural integrity of volcanoes such as: emplacement features, alteration conditions (either by past hydrothermal activity or weathering), tectonic stress, fracturing, discontinuities other than fracturing (i.e. strati $\neg$ fication, dikes, breccias, pyroclastic deposits), and water pressure, amongst the most important. Some external trig $\neg$ gering factors have to be considered also, for example, excessive rainfall and/or earthquakes. Although there are additional factors associated with volcanic instability, for instance those related to volcanic activity, they are not mentioned here because this paper is focused on factors affecting inactive or extinct volcanoes.

Cofre de Perote $(4,282$ m.a.s.l.) is an extinct volcano that has repeatedly collapsed long after its activity ceased (Carrasco-Núñez et al., 2006). It constitutes the northern end of the Citlaltépetl-Cofre de Perote Volcanic Range (CCPVR) at the eastern part of the Trans-Mexican Volcanic Belt (TMVB) (Figure 1).

The instability conditions for Cofre de Perote (CP) volcano have been attained by consideration of the factors described above in order to determine whether there are enough destabilizing elements to account for a renewed collapse, or if the volcano has become stable enough to be considered as a "safe" structure. This approach considers data extrapolated from overlapping failure models using limit equilibrium analysis, with stress/strain relationships obtained from finite element modeling. By combining these techniques, complemented by careful observations and aided by a reconstruction of ancestral collapses, we have obtained enough information to determine the maximum allowed deformation and stress required to induce failure.

\section{Geologic evolution of Cofre de Perote volcano}

From a morphological perspective, $\mathrm{CP}$ volcano can be defined as a compound shield volcano, as it has lowgrade slopes and does not have a single eruptive conduit, but rather the volcanic materials were extruded through several eruptive centers in a dome-like manner (Figure 2). Amongst CP's main morphological features are its soft slopes, which provide a deceptive perception that the vol $\neg$ canic edifice is stable.

The evolution of CP can be divided into three marked and distinctive construction stages and at least two confirmed destruction periods (Carrasco-Núñez et al., in preparation). The first stage of construction was dated by $\mathrm{K} / \mathrm{Ar}$ at about $1.3 \pm 0.1 \mathrm{Ma}$ (Carrasco-Núñez and Nelson, 1998) and corresponds to basaltic andesites located at the SE flank of Cofre de Perote. Some older lavas have been reported nearby, such as those collected east of Perote and dated at 1.7 and 1.9 Ma (Yañez-García and García-Durán, 1982), as well as one lava sample collected east of Xalapa and dated by Cantagrel and Robin (1979) at $1.57 \pm 0.05 \mathrm{Ma}$ (Pleistocene); nevertheless, the relation of these older lavas to the $\mathrm{CP}$ volcanic activity is not certain. This first stage of construction is characterized by intense effusive activity from multiple eruptive centers, which resulted in a large volcanic field that comprises the basal part of $\mathrm{CP}$ volcano. These observations could explain the difference in age, given the volcano is not comprised of a single structure, but in reality constitutes an entire volcanic field. The oldest lavas at $\mathrm{CP}$ volcano are mostly composed of olivine and augite basaltic andesite and do not present a strong contrast in composition (Carrasco-Núñez and Nelson, 1998). The dominant rocks belonging to the first stage of construction are porphyritic and occasionally show a seriated texture. The mineralogy of these rocks comprises mainly plagioclase and augite crystals within a matrix that includes microlites of plagioclase and pyroxenes. Some samples display alteration minerals, particularly iron oxides (hematite and/or magnetite) and skeletal and sieve textures are 


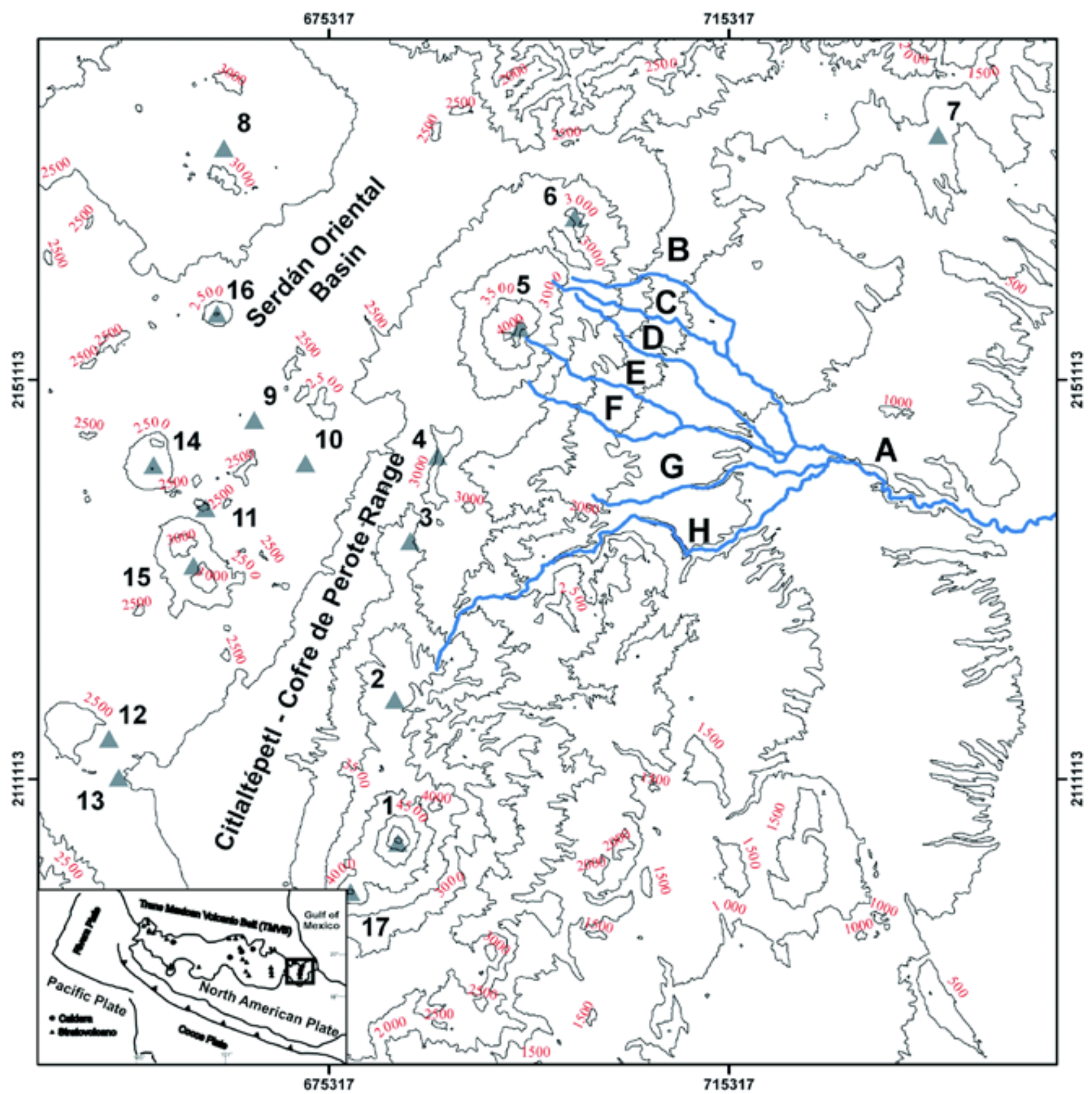

Figure 1. Location of Cofre de Perote volcano and main volcanoes of the region: Pico de Orizaba (1); Las Cumbres (2); Cerro Desconocido (3); Cerro Tecomales (4); Cofre de Perote (5); Las Lajas (6); Naolinco volcanic field (7); Los Humeros Caldera (8); Alchichica (9); Quechulac (10); Laguna de Atexcac (11); Tecuitlapa (12); Aljojuca (13); Cerro Pinto (14); Las Derrumbadas (15); Cerro Pizarro (16); Sierra Negra (17); Los Pescados River (A); Atopa River (B); Gavilanes River (C); Limon River (D); Teocelo River (E); Chico River (F); upper Los Pescados (G); Huitzilapan River (H).

visible in some plagioclase crystals. The mineralogy is similar in most samples belonging to this stage, with plagioclase and augite phenocrysts surrounded by a glassy re-crystallized matrix being the most characteristic features.

After a long period of quiescence, for which no record of volcanic activity is present, the second stage of construction started about 0.4 My ago (Carrasco-Núñez et al., in preparation); it is characterized entirely by effusive activity, as reported for earlier lavas. At this stage, lavas are clearly ooverlie deposits of the Xaltipán ignimbrite, dated at $0.46 \pm 0.02 \mathrm{Ma}$ (Ferriz and Mahood, 1984). Effusion rates for this period were apparently continuous until the cease of activity (Carrasco-Núñez and Nelson, 1998). Samples belonging to the second stage show a seriated porphyritic texture, similar to the rocks of the first stage. The rocks are mainly composed of plagioclase phenocrysts and two pyroxenes (hyperstene and augite). The matrix for these samples is coarse-grained and is mostly constituted by 
microlites of plagioclase, altered olivine crystals and magnetite, although glass is also present in a few samples.

The last stage of construction is constituted by rocks dated at $0.24 \pm 0.05 \mathrm{Ma}$ (Carrasco-Núñez and Nelson, 1998). These rocks vary in composition from intermediate to felsic and display characteristic porphyritic textures with plagioclase phenocrysts in a mi $\neg$ crolithic matrix with pyroxenes, magnetite and, in a few cases, recrystallized glass. In contrast with lavas corresponding to the first and second stages, skeletal textures are not present in the lavas of the last stage.

We have found no evidence of explosive activity for any of the construction stages of the volcano and, given its dimensions, it is not likely that the structure ever showed such behavior. However, evidence shows that lavas belonging to second stage of construction are overlying pyroclastic deposits belonging to Los Humeros caldera, particularly toward its western flank. These deposits correspond to the Xaltipán ignimbrite (Ferriz and Mahood, 1984).

The last evolutionary stage of CP volcano is marked by two periods of destruction that generated massive collapses at about $42 \mathrm{~K}$ and $10 \mathrm{~K}$ years ago (Carrasco-Núñez et al., 2006). These events produced widespread volcanoclastic deposits towards the east long after the cease of CP activity $(0.24 \pm 0.05 \mathrm{My})$. Those deposits are known as Los Pescados Debris Flow and Xico Avalanche, respectively (CarrascoNúñez et al., 2006).

\section{Structural parameters affecting the instability of Cofre de Perote volcano}

Stability conditions described below are similar to those involved in any rock mass structural quantification (i.e. Cai et al., 2007; van Wyk de Vries and Borgia, 1996); however, the regional tectonic setting and local volcanic stratigraphical conditions must be considered for an appropriate stability assessment.

For a comprehensive stability assessment of a volcanic edifice, regardless of its size, a detailed description of the factors affecting its structural integrity is required. In most cases, volcanic instability is only evaluated from a general and/or descriptive point of view (i.e. Carrasco-Núñez et al., 2006; López and Williams, 1993); however, sometimes a more quantitative methodology is used (i.e. ConchaDimas et al., 2005). The quantitative approach presented here considers modeling that can be used either as a single methodology or in combination with other methods for assessing the structural conditions of volcanic structures and other types of rock masses.

The first step in a structural evaluation should be to obtain the mechanical parameters that will be used in the model. Detailed geology and knowledge of representative structural features are fundamental for assessing structural properties, fracturing being the most significant factor given its importance to rock mass structural behavior.

In addition, hydrothermal alteration has been proposed as a major weakening factor by several authors (Watters and Delahaut, 1995; López and Williams, 1993); therefore, the intensity and distribution of alteration has to be assessed when determining structural integrity. The role of alteration is very important in restricting the rock mechanical response at altered areas nearby or next to brecciated deposits, usually underlying massive and unaltered lava flows.

\section{Fractures}

Major structural features represented on the geologic map (Figure 2) are most likely related to tectonic aspects. They were identified from digital aerial ortorectified images (scale 1:20,000, pixel size 2 meters) in order to delineate major fractures and alignments (Figure 3). Rose diagrams reveal a NE-SW preferential orientation, which is parallel to the structural alignment followed by three volcanoes comprised by Cerro Desconocido, Cofre de Perote and Las Lajas. According to Lagmay et al. (2000) and Nakamura (1977), this alignment might indicate the principal horizontal stress $(\sigma 2)$, where $(\sigma 1)$ would cor $\neg$ respond to the gravitational load of the structure over the supporting surface.

Rose diagrams of fractures were elaborated following two different criteria: by fracture density (Figure 3a) and by fracture length (Figure $3 b$ ). We identified at least three major fracture patterns: NW-SE, N-S, and NE-SW. If tensile forces determine fracture orientation, slip surfaces should follow a direction normal to the mean fracture orientation, indicating the most likely direction of failure in a sector is oriented parallel to the tensile horizontal stress (normal to main scarps). Furthermore, results from direct field measurements represented by pole diagrams indicate a similar stress orientation mainly NW-SE and N-S (Figure 4).

\section{Basement control}

Carrasco-Núñez et al. (2006) proposed that along the CCPVR the sloping substrate was one of the most important factors controlling the collapse of all major volcanic structures towards the east. This is supported also by observing the folding orientation of the basement structures (Concha-Dimas et al., 2005), and the interpretation of the rose diagrams of faults generated over the supporting tilted limestones (Mossman and Viniegra, 1976), which have facilitated collapses towards the east. In any case, under these conditions fractures are expected to be normal to the direction of tilting (Merle and Borgia, 1996), rendering the basement as the controlling mechanism for induced structural instability and failure direction of the collapsed volcanoes. 


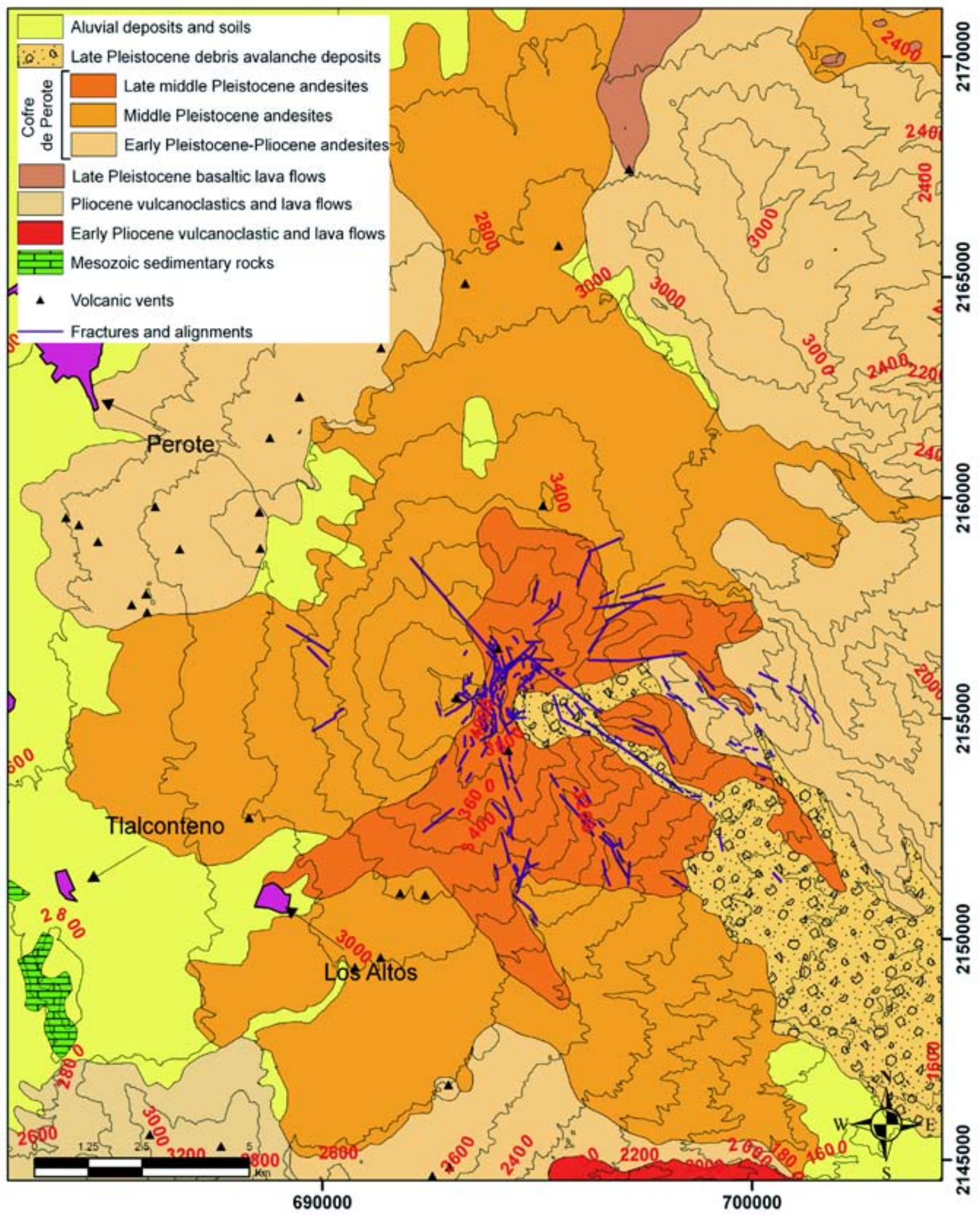

Figure 2. Geology of Cofre de Perote volcano. Contour lines at every $200 \mathrm{~m}$; solid triangles indicate volcanic vents and colored lines indicate fractures and/or alignments. Geographic coordinates are on UTM Ellipsoid GRS80. Modified after Carrasco-Núñez et al. (in 


\section{Mechanical characterization of Cofre de Perote volcano}

So far, only structural parameters such as fractures and orientations have been considered, however, in order to evaluate local slope instability, two fundamental aspects need to be considered: discontinuities and rock properties. Discontinuities are comprised of joints, stratification, foliation, faults and fractures, and all are considered as planes of weakness (Watters et al., 2000). Chemical alteration of rocks is another important factor to be considered, as intact rock strength varies according to the intensity of alteration, where intensely altered rocks have a very low strength. Also, alteration in discontinuities such as joint filling has to be considered when describing the rock mass (Bieniawski, 1989).

Determination of rock structural properties is difficult because rock fabric differs from most studied materials and the rock properties are far from behaving in an "ideal" form, being anisotropic, heterogeneous and discontinuous. Although rock mass strength varies in some cases up to several orders of magnitude from that of the intact rock, rock strength represents the upper limit of strength for any given rock mass (Bieniawski, 1989).

Mechanical behavior of fresh rocks without secondary fractures can be considered as elastic materials that experience fragile failure, rendering very high elastic moduli and a limited ability for deformation. In contrast, rock masses are dependant on rock strength and behave more as plastic materials. They are affected by the number and distribution of discontinuities and allow stronger deformation with continual stress/strength redistribution as slopes deform. We extracted core probes from selected samples collected at the Cofre de Perote summit in order to determine intact rock strength. Selection of these rocks was done according to visual variations in chemical alteration conditions, varying from apparently fresh to strongly altered rocks. Samples were tested under axial load (Figure 5) following ASTM (American Society for Testing Materials) compliances (ASTM Standard D7012, 2007). Different rock mechanical responses were observed under axial load, whereas one of the samples presented relatively higher resistance, showing an abrupt failure (Figure 5a) and suggesting fragile failure, another sample failed more rapidly presenting a series of fractures with different orientations (Figure 5b).

Mechanical response and vertical deformation of rocks from several locations at the CP summit were measured by using a Schmidt hammer, and strain/stress diagrams were drawn to determine the type of failure, and rock strength (Table 1).

The main parameters obtained through mechanical testing were strain/strength relations, elastic modulus (E), maxi $\neg$ mum stress allowance $(\sigma)$ and deformation $(\varepsilon)$ (Table 1).

Strength results suggest that an external factor such as hydrothermal alteration might be responsible for the low resistance obtained in the laboratory and in the field (Díaz Castellón, under revision)

Because wave propagation is ruled by density and Lamé parameters, some sites were selected for geomechanical profile characterization using the $\mathrm{Vp} / \mathrm{Vs}$ (compression and shear velocity) ratio (Álvarez-Manilla et al., 2003). Travel time of "S" and "P" waves determines elastic characteristics of the media, and corresponds to shear and compressive waves. These signals are compared with the distance from the acoustic source and registered against the arrival time.

Seismic waves propagate throughout a discontinuous media according to Hook's Law, and are transmitted in two forms: dilatation or compression (also known as "P" waves); and transversal or shear (also known as "S" waves). The Poisson Ratio, Rigidity, Young, and Bulk Dynamics Deformation Modulus were determined by using the propagation velocity and bulk density relationship. A final parameter derived from seismic survey by the ratio "Vp/Vs" was the internal friction angle, under elastic deformation according to Álvarez-Manilla et al. (2003).

\section{GSI Geological Strength Index}

The Geological Strength Index (GSI) is one of the most widely used methods to characterize the structural features of any given rock mass, using descriptive conditions of the rock mass (i.e. Bieniawski, 1973). Despite the fact that the parameter is highly effective, Cai et al. (2004) have proposed method to assess the GSI in a semi-quantitative way, considering several quantifiable parameters to achieve a highly acceptable and more adequate index.

In this paper, we approach the problem by using digital image analysis. To estimate the rockmass area, an initial calibration of the pixel size is required, and after a pre- processing treatment involving the enhancement of structural features, the image is separated into rock and fractures, and finally an estimative value of the GSI is obtained.

However, the method cannot consider some factors such as fracture condition and alteration; therefore, a detailed description of the fractures including filling material, water, type of joints and alteration is necessary for pixel calibration. These considerations are introduced into the kernel used to calibrate the image, in order to obtain a more accurate GSI (Figure 6). Using the traditional method for GSI, where alteration or fracture conditions are not considered, a value of 0.866 was obtained, which differs from our estimate of 0.78 (Table 2). The main difference between both techniques is that our method considers the rock $\neg$ wall while traditional measurement considers only a one-dimension analysis. Consequently, it is expected that GSI values in digital evaluation are more conservative than traditional methods; nevertheless, it should be more accurate. 

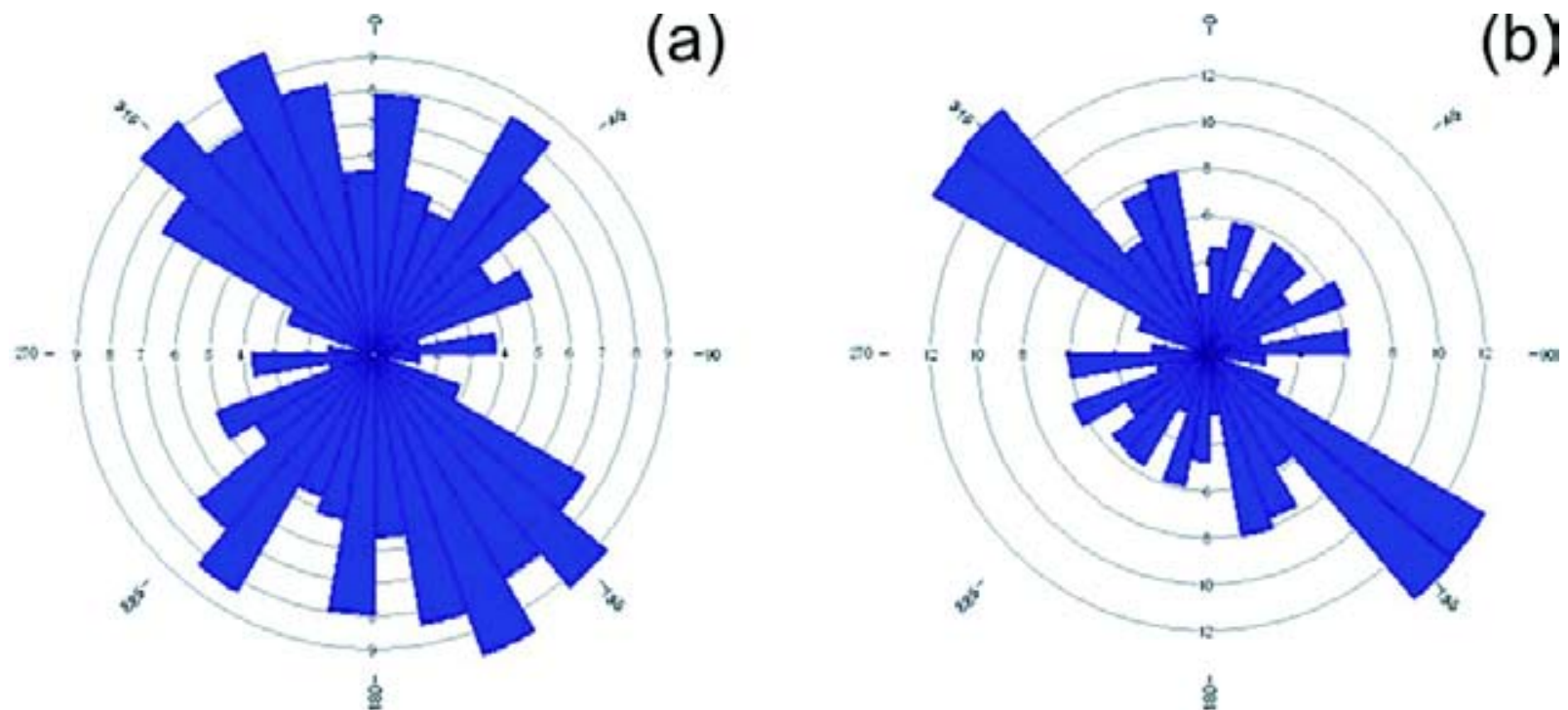

Figure 3. Rose diagrams, obtained from aerial imagery (INEGI 1:20,000 Orthorectified photos, pixel size 2m): a) Structural alignments according to density. b) It shows orientation according to length.

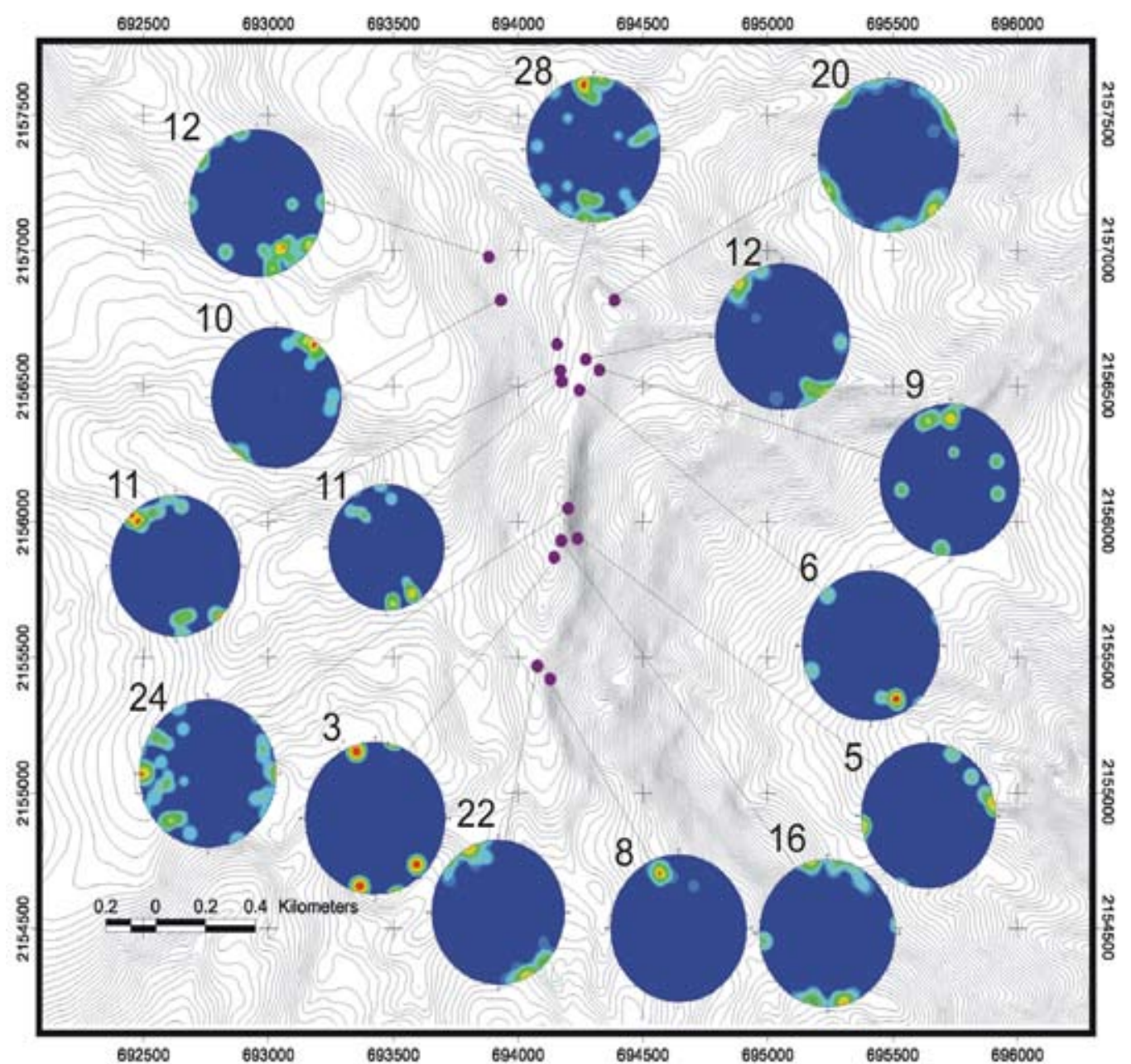

Figure 4. Pole diagrams at CP volcano's summit. Numbers at the left of each diagram indicate the number of readings taken in the 


\section{Limit equilibrium analysis}

In order to determine the mechanical conditions of the volcano, a reconstruction of its summit was carried out based on present topographical conditions, and estimated volume of the volcaniclastic deposits from past collapse events. For that purpose, the paleotopography was obtained (Figure 8 ) by interpolating the missing elevation contours and softening the scarp configuration (Figure 7) to a slope similar to that of the eastern lower flanks.

The limit equilibrium analysis approaches a problem through lineal comparison of active Vs resisting forces. All acting forces (af) (negative) and resisting forces (rf) (positive) are added, and equilibrium is considered to be present if the result is positive or "zero", and "zero" is considered as limit equilibrium. Another approach named the "safety factor (SF)" consists of dividing both sets of forces ( $\mathrm{rf} / \mathrm{af}$ ), "one" being the lowest value for equilibrium. This is the most widely used method in numerical modeling for most engineering projects, including the present work

Using more precise data makes it possible to get closer to a "safety factor" of one, in contrast, a safety factor of two or even larger might not mean anything if the input data is corrupt or statistically poor.

The limit equilibrium analysis performed in this paper follows the Hoek et al., (2002) criterion and uses the commercial software named "Slide" (Rocscience, 2003), where failure surfaces are estimated according to constitu $\neg$ tive equation proposed by Mohr-Coulomb, where shear strength is controlled by the relation $\tau=\mathrm{c}+\sigma \tan (\varphi)$, and where: $\tau=$ shear strength; $c=$ cohesive strength; $\sigma=$ uniaxial compressive strength; $\varphi=$ internal friction.

This condition suggests a lineal behavior of a slip surface which according to Hoek et al., (2002) might yield unrealistic safet safety parameters and lead to underestimate stability conditions at any given slope.

To compensate for such underestimations, Hoek et al.,
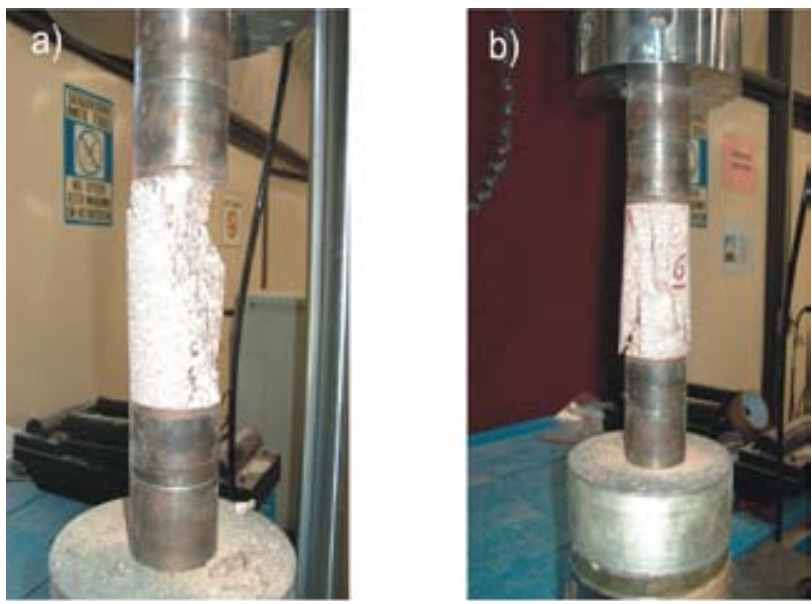

Figure 5. Uniaxial compressive tests in rock cores from Cofre de Perote volcano summit: a) slightly altered sample showing failure under higher strength; b) strongly altered sample with lower strength.
(2002) proposed a model to estimate mechanical properties of rock masses since 1980, which has evolved up until today and it is expressed in the form:

$$
\sigma_{1}=\sigma_{3}+\sigma_{c i}\left\{m_{b} \frac{\sigma_{3}}{\sigma_{c i}}+s\right\}^{a}
$$

(Generalized Hoek and Brown criterion 1997)

Where: $\sigma_{1}, \sigma_{3}=$ major and minimal principal strengths; $\sigma_{c i}=$ uniaxial compressive strength; $m_{b}, s, a=$ Hoek and Brown constants.

Constants "s" and " $\mathrm{m}$ " depend on a physical alteration parameter designated as disturbance (D) (Hoek et al., 2002); this parameter influences both constants and for the present evaluation, it has been interpreted as loss of confinement because of a missing part of the structure. In other words, tilting of the basement or basement deformation due to emplacement of the volcanic edifice, along with loss of confinement from the missing summit, help increase the disturbance factor "relaxing" its summit and favoring unstable conditions of the volcanic edifice.

\section{Limit equilibrium analysis on a reconstructed $C P$}

Regardless of the triggering factors that caused the volcano to collapse, relaxation due to the retirement of confinement from missing parts of the summit, irregular basement support, rock weakness due to hydrothermal alteration (Díaz-Castellón et al., 2004) and strong fracturing are amongst the most important structural parameters controlling instability of the volcano. Results from a seismic exploration survey suggest that relaxation of the summit is possible. In a test conducted normal to the main scarps, acoustic wave travel velocities were reported to be slower than those observed parallel to the main scarps, suggesting that a stronger fracture pattern is present in that direction with tension fractures formed in the same direction.

Relaxation of the summit suggests that a high disturbance factor $(\mathrm{D}=0.7)$ (Hoek et al., 2002) should be used in the numerical evaluation. A comparison of the actual topo $\neg$ graphical cross section, derived from an elevation model using 1:50,000 scale digital topographical data from INEGI (1984, 1987a, 1987b, 1990) (E14B26, E14B27, E14B36, E14B37) with a modified section showing the inferred paleotopography is shown in Figure 8. The geological cross sections were obtained from available data (Figure 2). Although the model is simple, it comprises the main structural parameters identified in the field and from laboratory tests. Because the model considers the constitutive equation proposed by Mohr Coulomb, and the model approaches the problem through the constitutive equations of Hoek et al. (2002), the authors suggest here an empirical model to adjust from the generalized Hoek and Brown (1997) criteria to the Mohr Coulomb model.

The first reconstructed model considers normal gravitational forces because of the presence of the volcanic 


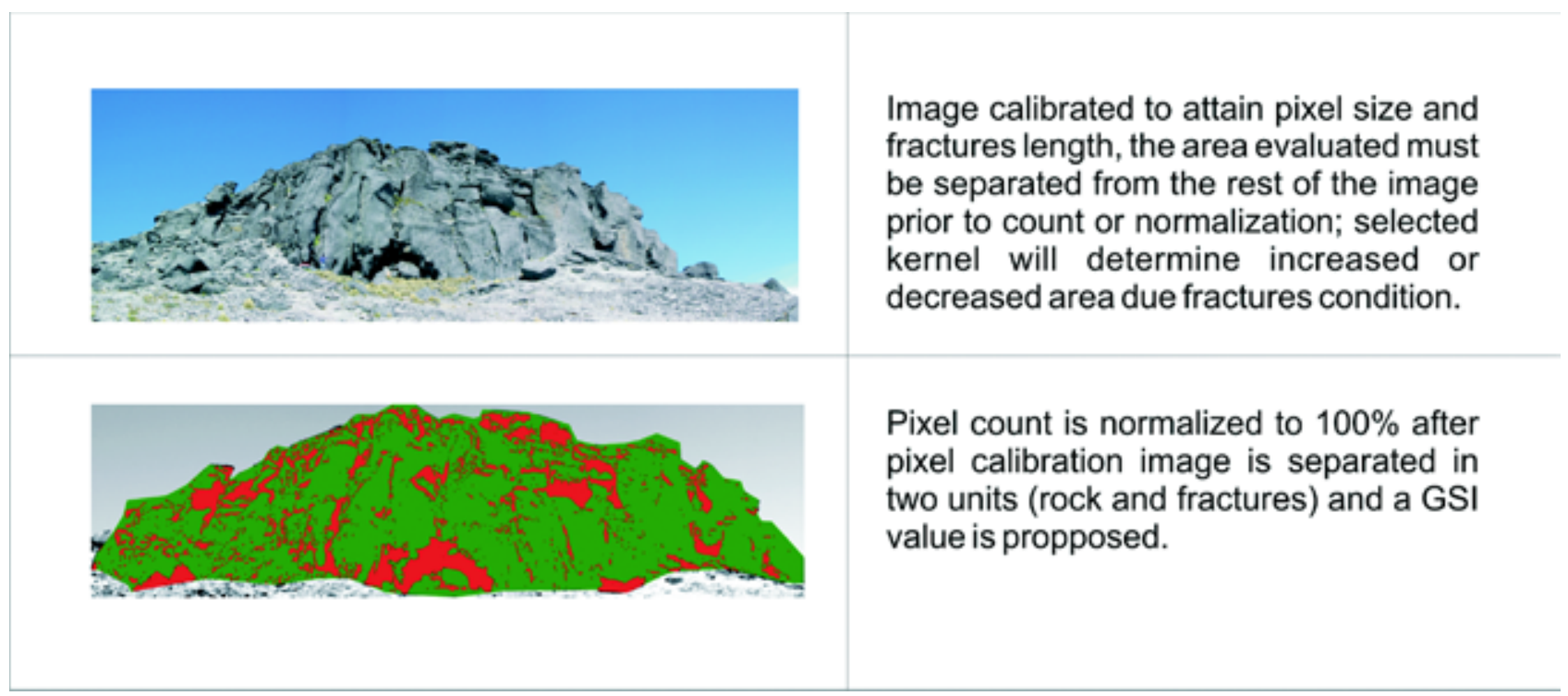

Figure 6. GSI parameter determination for rockwalls at CP summit

Table 1. Results from uniaxial compressive tests at the laboratory.

\begin{tabular}{lllllllll}
\hline Sample & Height $(\mathbf{c m})$ & Strain $(\mathbf{m m})$ & Failure KN & Time $(\mathbf{s})$ & $\varepsilon$ & A $\left(\mathbf{c m}^{2}\right)$ & s $(\mathbf{M P a})$ & $\mathbf{E}(\mathbf{G P a})$ \\
\hline 030602A9 & 12.83 & 1.06706 & 117.76 & 243.1 & 0.008317 & 20.268299 & 58.1026 & 6.986072082 \\
030602B5 & 14.20 & 0.89410 & 97.27 & 299.4 & 0.006296 & 20.268299 & 47.9914 & 7.621949998 \\
030602B6 & 12.90 & 0.96050 & 95.93 & 238.4 & 0.007446 & 20.268299 & 47.3287 & 6.356481785 \\
030602B7 & 13.24 & 1.00940 & 101.59 & 255.6 & 0.007624 & 20.268299 & 50.1241 & 6.574627733 \\
030602B8 & 13.60 & 0.79190 & 82.02 & 236.9 & 0.005823 & 20.268299 & 40.4651 & 6.949432132 \\
030602C1 & 13.56 & 0.99800 & 34.57 & 50.9 & 0.007360 & 20.268299 & 17.0582 & 2.317729399 \\
030602C2 & 14.04 & 0.79405 & 45.53 & 146.4 & 0.005656 & 20.268299 & 22.4615 & 3.971528044 \\
\hline
\end{tabular}

$\varepsilon=$ deformation; $\mathrm{A}=$ area; $\sigma=$ uniaxial compressive strength; $\mathrm{E}=$ elastic moduli

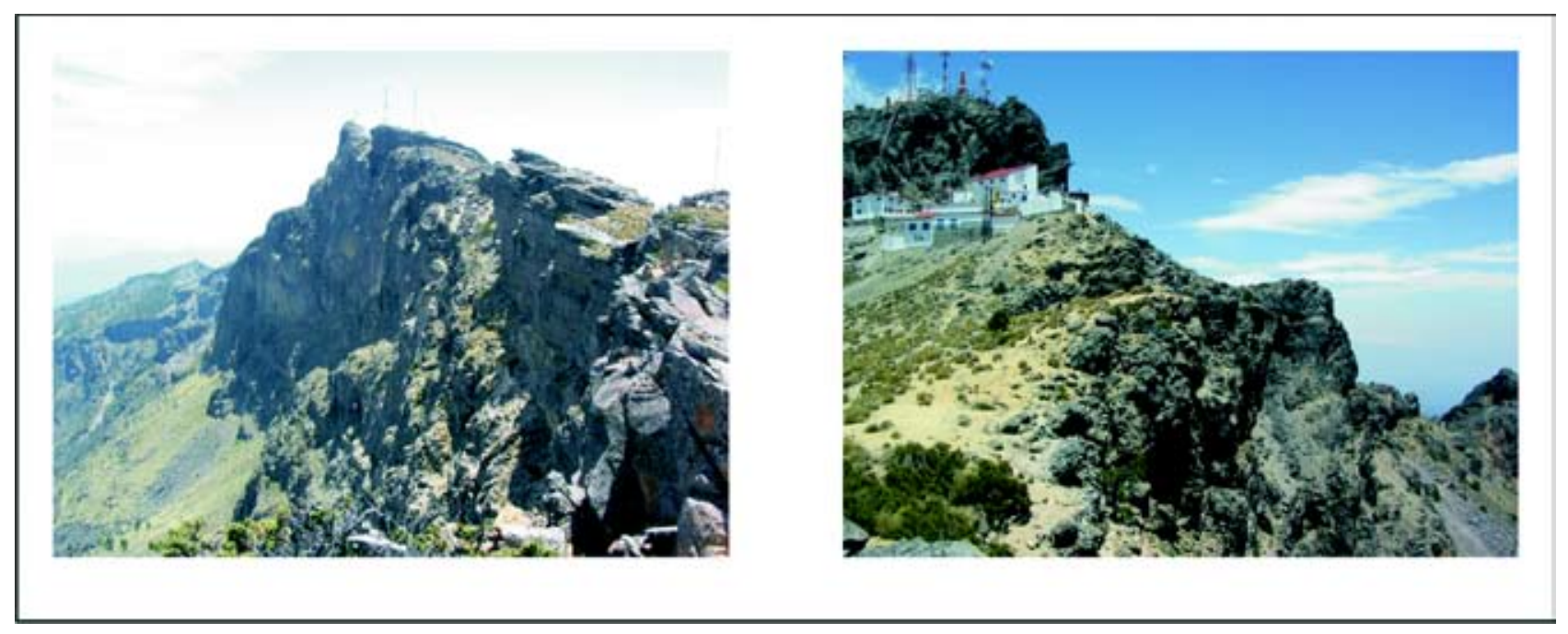

Figure 7. Main scarps at Cofre de Perote volcano showing its spectacular cliffs, which reach up to 300 meters vertically 
Table 2. GSI from large outcrops located at the summit of Cofre de Perote volcano

\begin{tabular}{llllll}
\hline Image & Solid count & Fracture count & Fracture relation & Rock relation & GSI \\
\hline 1 & 379.43 & 104.35 & 0.22 & 0.78 & $78 \%$ \\
2 & 482.70 & 87.94 & 0.15 & 0.85 & $85 \%$ \\
3 & 117.21 & 30.81 & 0.21 & 0.79 & $79 \%$ \\
4 & 181.34 & 81.21 & 0.31 & 0.69 & $69 \%$ \\
5 & 455.56 & 616.839 & 0.58 & 0.42 & $42 \%$ \\
\hline
\end{tabular}

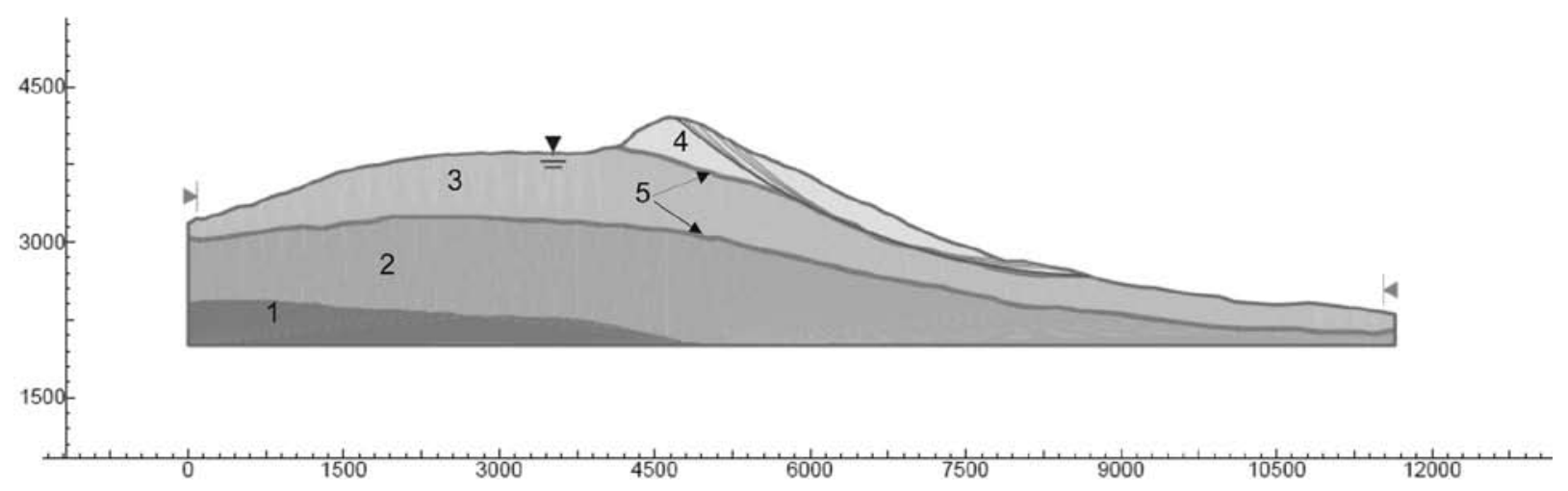

Figure 8. Multiple failure surfaces considering a safety factor of 1.0 or below and where the lowest SF considered belongs to an SF of 0.798 . Numbered stratigraphical sections: 1) Mesozoic limestone, 2) Early Pleistocene-Pliocene andesite, 3) Middle Pleistocene andesite, 4) Late mid $\neg$ dle Pleistocene andesite, 5) Pyroclastic and/or breccia deposits.

massif. Under normal conditions the modeling shows multiple failure surfaces, which do not reach instability conditions. The selected surface for numerical evaluation was done by taking the largest slip surface closest to limit equilibrium (Figure 8), that is, the largest surface area, which was closest to 1 in the most critical scenario. For our approach we selected Bishop's modified method and a model comprised of 20 slices or sections.

Seismic acceleration and an increased neutral pressure induced by a hydrostatic water column can be proposed as the main triggering factors, however, because of the rock mass characteristics and height of the waterhead, it becomes clear that hydrostatic pressure might not create unstable conditions. Nevertheless, several calculations varying the height of the waterhead indicated that excess hydrostatic pressure is not likely to destabilize the structure. Liquefaction as a seismically induced process provoked by a reduced resistance to shear strength (Colindres-Selva, 1993) can also be a factor to be considered; however, results indicate that this is not a likely scenario because the principal requirements, hydrostatic pressure and a granular media, are not present at CP. Furthermore, numerical verification confirmed that water does not represent a destabilizing element in this particular case.

To determine instability conditions of the reconstructed volcano modeled under stable conditions, a constant horizontal pull of $0.1 \mathrm{~g}$ was applied in an attempt to simulate seismic acceleration. In order to have consistent results, we proposed the same failure surface used to assess structural conditions in the reconstruction of the static model (Figure 8).

Although we lack acceleration information for the CCPVR area and $0.1 \mathrm{~g}$ might seem arbitrary, there are records of a historic 6.5 Richter magnitude earthquake named the Xalapa earthquake of 1920 (Flores and Camacho, 1922; Suárez, 1992), that factor alone suggests this type of acceleration could be achieved. For that reason, and based on an acceleration model prepared for the western United States (Mualchin, 1996), we found that a relatively low 5.2 Richter magnitude earthquake at a maximum distance of $15 \mathrm{~km}$ could be enough to accelerate the ground and reach the proposed $0.1 \mathrm{~g}$.

Our results suggest that if such acceleration is reached it would result in a force strong enough to destabilize the volcano from an "SF" of 1.053 to 0.798 . However, we recognize that further analysis will be needed to verify those considerations.

\section{Finite element analysis}

In contrast with limit equilibrium, our determinations using finite element analysis approaches the problem considering rock mass strength rather than rock strength to determine strain/stress relationships. These parameters, strong earthquake would be enough to destabilize the structure and induce failure of its summit. 


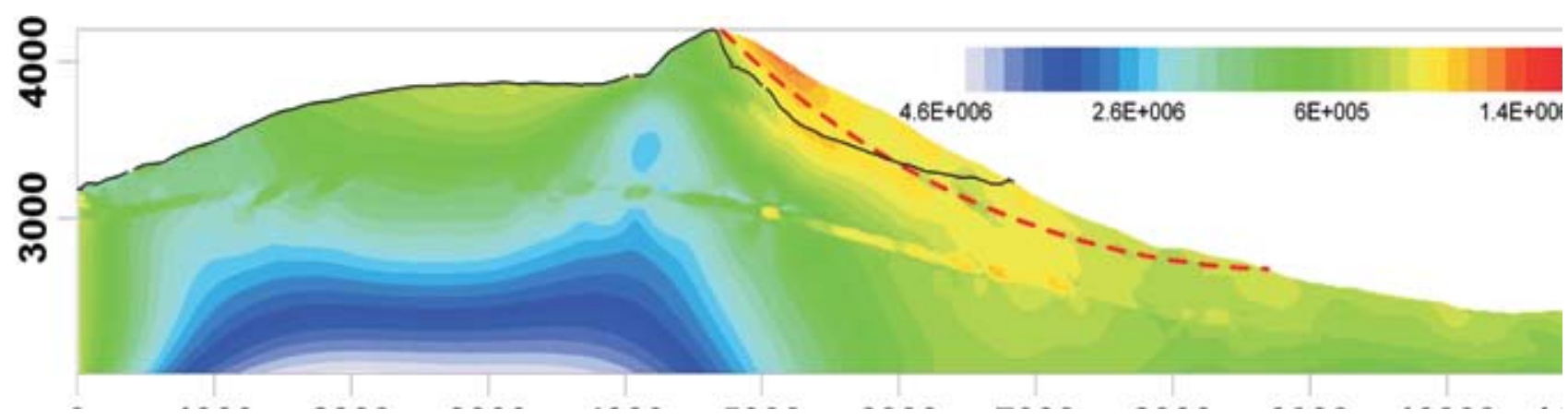

Figure 9. Shear stress on reconstructed CP volcano. The dotted line represents the calculated failure surface and the continuous line represents present topographical cross section.

derived from rigidity and bulk modulus ("G" and " $\mathrm{K}$ "), are determined directly in the field aided by seismic refraction exploration methods.

The modulus mentioned above along with the other parameters (Table 3) are drawn directly from the relationship of the propagation velocities between dilation or compression waves (VP) and the transversal or shearing waves (VS) (Álvarez-Manilla et al., 2003) where:

$$
\begin{gathered}
V_{p}=\sqrt{\frac{K+\frac{4}{3} G}{\rho}} \\
V_{s}=\sqrt{\frac{G}{\rho}}
\end{gathered}
$$

Mechanical results were applied to the reconstructed $\sec \neg$ tions used on limit equilibrium analysis at $\mathrm{CP}$; where strain/stress was plotted considering shear conditions. Actual methodology considers total stress energy deformation.

To follow the same criteria, we used again a horizontal pull of $0.1 \mathrm{~g}$ caused from a seismic dynamic load, and a vertical gravitational acceleration of $1 \mathrm{~g}$.

The deformation field $(\Lambda(\mathrm{e}))$ is assessed through the expression of energy where a deformation continuum can be proposed for each finite element by means of the expression:

$$
\Lambda^{e}=\frac{1}{2} \int\{e\}^{T}[D]\{e\} d V-\int\{e\}^{T}[D]\left\{\epsilon_{t}\right\} d V
$$

Where: $\left\{\varepsilon_{\mathrm{t}}\right\}=$ Thermal deformation field; $[D]=$ Elastic constants matrix, $\{e\}=$ Total deformation.

To produce an accurate mesh of the section, it is necessary to use finite elements with second degree shape constants because the section is complex, especially when attempting to mesh finite elements that are larger that the minimum separation between distances comprising the section. In the case of a finite element of four sides, which is the type used for the present model, each element has eight shape constants with two degrees of freedom on each node of the finite element $(\mathrm{X}, \mathrm{Y})$.
The main input parameters used to evaluate strain/stress conditions were: gravitational acceleration, maximum horizontal pull of $0.1 \mathrm{~g}$, elastic modulus, and Poisson relationship of slopes retrieved from seismic exploration (Table 3). Since the model used to evaluate stability is a $2 \mathrm{D}$ section, the mechanical model approaches a solution through planar deformation, therefore, it is necessary to suggest a thickness for each section, which in this case is unitary $(1 \mathrm{~m})$.

Constitutive equations applied to each finite element allow to evaluate creep, strain, stress and hardening.

For most of the sections, finite element meshing was at a separation of $50 \mathrm{~m}$ between each finite element where massive layers of lava and basement rocks are present. For other materials such as pyroclastic and/or breccia deposits, a finer mesh was elaborated, considering a separation between continuous elements of $20 \mathrm{~m}$.

Results of the reconstruction of CP volcano's summit considering a $0.1 \mathrm{~g}$ acceleration gave us an estimated shear stress distribution for the section. After overlapping the results from limit equilibrium analysis on the shear stress model, it is possible to obtain an estimation of shear stress at the time of failure (Figure 9). A second model of shear strain was elaborated to determine the maximum deformation allowed at the time of failure. Estimation results suggest the maximum strain allowance at the time reaches critical conditions (Figure 10).

\section{Evaluation of the present structural conditions at CP volcano}

In order to assess the present structural conditions at $\mathrm{CP}$ volcano we used the same methodology applied to the reconstruction of the volcano; however, in this case and in order to increase accuracy, six sections were produced, which are perpendicular to the scarps and consistent with fracturing conditions.

The first results from the six sections evaluated show large failure surfaces, which are slightly above an SF of 1 or very close to it (Figure 11). After a horizontal pull of $0.1 \mathrm{~g}$ was applied (Table 4) it becomes clear that a relatively 


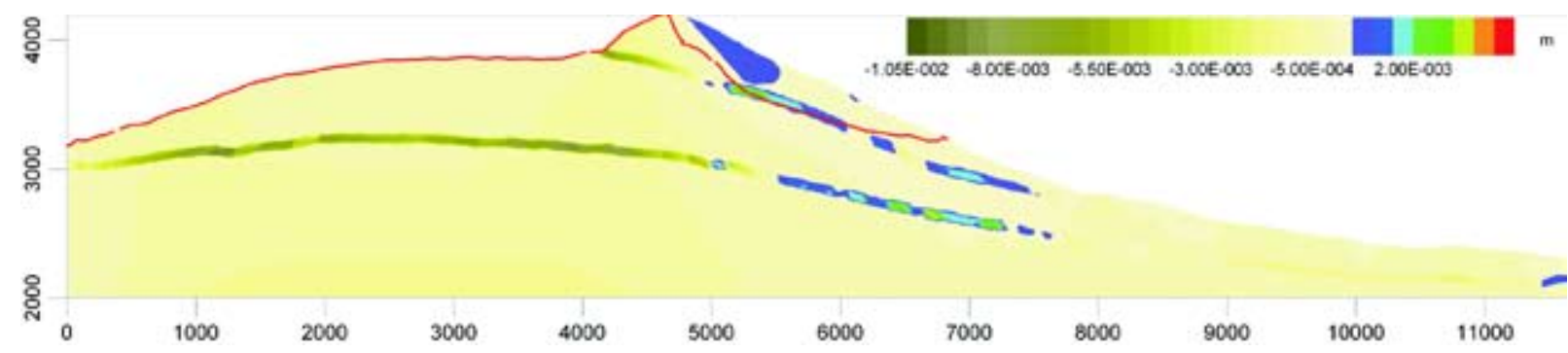

Figure 10. Shear strain along reconstructed section on CP volcano, red (continuous) line represents present topographical cross section.

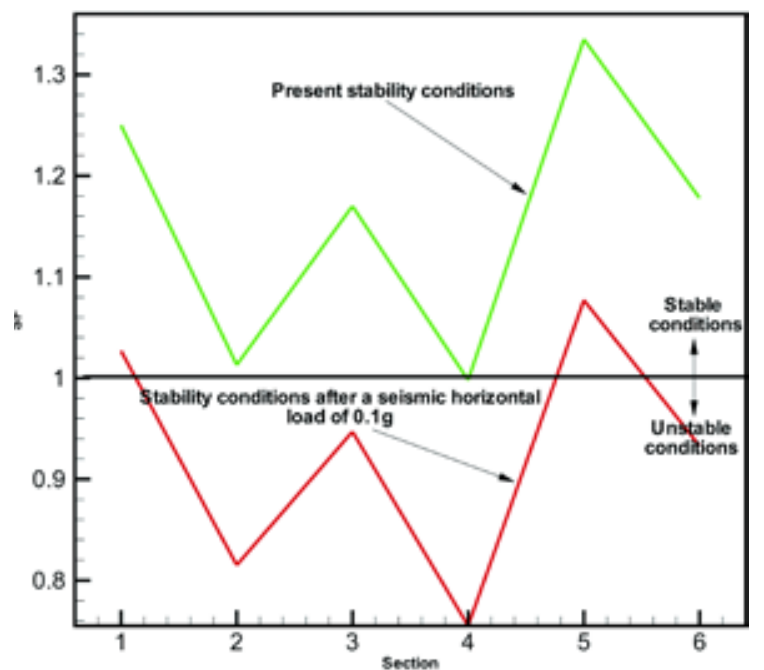

Figure 11. Instability prior to and after a horizontal seismic load of $0.1 \mathrm{~g}$ was applied to the 6 studied sections at Cofre de Perote volcano's summit..

Table 3. Mechanical relations obtained from seismic refraction survey at CP volcano.

\begin{tabular}{llllllllllll}
\hline SSR & layer & $\begin{array}{l}V_{\mathrm{p}} \\
\mathrm{m} / \mathrm{s}\end{array}$ & $\begin{array}{l}V_{\mathrm{s}} \\
\mathrm{m} / \mathrm{s}\end{array}$ & $n$ & $\begin{array}{l}\gamma_{m} \\
\mathrm{kN} / \mathrm{m}^{3}\end{array}$ & $\begin{array}{l}E \\
\mathrm{kN} / \mathrm{m}^{2}\end{array}$ & $\begin{array}{l}G \\
\mathrm{kN} / \mathrm{m}^{2}\end{array}$ & $\begin{array}{l}K \\
\mathrm{kN} / \mathrm{m}^{2}\end{array}$ & $\begin{array}{l}\mathrm{hi} \\
\mathrm{m}\end{array}$ & $\begin{array}{l}\mathrm{Ti} \\
\mathrm{seg}\end{array}$ & $\begin{array}{l}\mathrm{f} \\
\mathrm{o}\end{array}$ \\
\hline 1 & 1 & 446 & 204 & 0.368 & 16.5 & 9,194 & 3,360 & 11,629 & 0.507 & 0.010 & \\
& 2 & 754 & 411 & 0.288 & 20.1 & 21,296 & 8,267 & 16,743 & 29.493 & 0.287 & 30 \\
& 1 & 353 & 141 & 0.405 & 16.3 & 6473 & 2304 & 11327 & 1.171 & 0.033 & \\
& 2 & 926 & 503 & 0.290 & 21.5 & 27921 & 10818 & 22209 & 7.173 & 0.057 & 30 \\
& 3 & 2273 & 1315 & 0.248 & 22.5 & 73880 & 29596 & 48894 & 16.656 & 0.051 & 39 \\
& 1 & 435 & 203 & 0.361 & 16.3 & 9006 & 3310 & 10763 & 1.265 & 0.025 & \\
& 2 & 734 & 383 & 0.313 & 20.1 & 20204 & 7692 & 18036 & 4.007 & 0.042 & 25 \\
& 3 & 1000 & 555 & 0.278 & 21.2 & 30050 & 11758 & 22547 & 35.000 & 0.252 & 35 \\
& 1 & 263 & 112 & 0.390 & 16.3 & 5067 & 1823 & 7662 & 1.184 & 0.042 & \\
& 2 & 708 & 378 & 0.300 & 20.1 & 19776 & 7606 & 16482 & 5.377 & 0.057 & 26 \\
& 3 & 1351 & 768 & 0.261 & 21.6 & 41855 & 16591 & 29232 & 35.000 & 0.182 & 36 \\
& 1 & 448 & 218 & 0.344 & 16.5 & 9679 & 3600 & 10361 & 3.601 & 0.066 & \\
& 2 & 2727 & 1596 & 0.240 & 22.7 & 89819 & 36229 & 57486 & 21.399 & 0.054 & 48 \\
& 1 & 470 & 229 & 0.344 & 16.4 & 10103 & 3758 & 10815 & 0.922 & 0.016 & 31 \\
& 2 & 1042 & 569 & 0.288 & 21.5 & 31486 & 12225 & 24729 & 24.078 & 0.169 & 31 \\
& 3 & 806 & 423 & 0.311 & 20.4 & 22599 & 8621 & 19902 & 35.000 & 0.331 & 23 \\
\hline
\end{tabular}

$v=$ Poisson relationship; $E=$ elasitic moduli; $\mathrm{G}=$ rigidity moduli; $\mathrm{K}=$ bulk moduli; $\varphi=$ internal friction angle; $V_{p}=$ dilatation or compression waves; $V_{s}=$ transversal or shear waves; $\gamma_{m}=$ material density. 


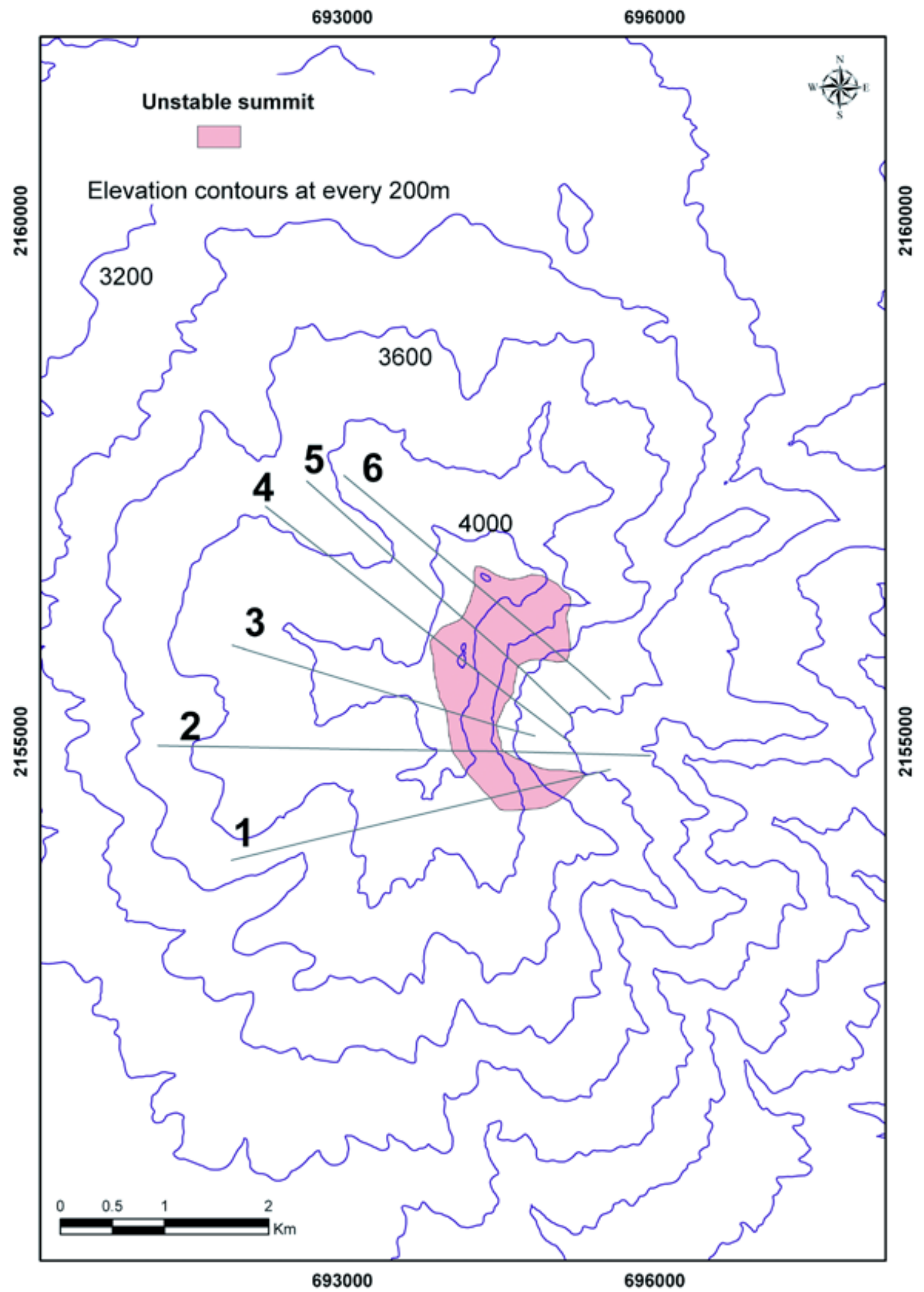

Figure 12. Results from finite element and limit equilibrium analysis under a $0.1 \mathrm{~g}$ horizontal acceleration. Unstable summit zone is shown in dark shaded pattern. Lines and numbers indicate sections used in the quantification of instability (1 through 6). 
Table 4. Safety factor (SF) before and after a horizontal load of $0.1 \mathrm{~g}$

\begin{tabular}{cll}
\hline Section No & $\begin{array}{l}S F \text { before } \\
\text { horizontal } \\
\text { seismic load }\end{array}$ & $\begin{array}{l}S F \text { after } \\
\text { horizontal } \\
\text { seismic load }\end{array}$ \\
\hline 1 & 1.25 & 1.027 \\
2 & 1.013 & 0.815 \\
3 & 1.17 & 0.947 \\
4 & 1.335 & 1.077 \\
6 & 1.178 & 0.933 \\
\hline
\end{tabular}

Evaluation of all sections, considering both methods, shows that an estimated 700-1,000 KPa shear strength might be enough to trigger collapse. Graphics for all sections were elaborated considering average areas and depths, where an estimated $0.5 \mathrm{~km} 3$ of material (Figure 12) is prone to collapse if a strong earthquake takes place near $\mathrm{CP}$.

\section{Discussion}

The methodologies discussed here have been derived from techniques and models widely used in engineering projects, although they are usually applied separately. Here, different techniques are combined to determine strain/stress relations on the volcanic massif. Additional methods such as digital image processing helped to determine the mechanical parameters of rock masses in an innovative way of determining the GSI, which must be used along with the Hoek and Brown constitutive equations for the determination of the Hoek and Brown (1997) constants. Moreover, evaluation of instability conditions at Cofre de Perote volcano must be considered an important issue for civil protection, especially because large populated areas are located on top of deposits from previous collapses of CP. This is the first approach to consider geotechnical instability conditions of the volcano's summit.

Structural parameters of the $\mathrm{CP}$ volcano are strongly associated to its geologic evolution and are affected by external mechanical processes, which are more characteristic of the structure itself. Nevertheless, many of its structural features that are visible today are clearly inherited from the regional volcanic tectonic settings.

From the reconstruction of CP volcano, it is clear that instability conditions in the past were similar to those that are present today, and that reconstruction of past events renders close results to those observed today at its summit. These observations also confirm that our structural considerations are adequate.

Although our estimations show that even an earthquake similar to the Xalapa earthquake of 1920 could trigger a sector collapse, there is still uncertainty as to what happened at $\mathrm{CP}$ summit during this event. All reports indicate that it triggered landslides of several slopes along the Huitzilapan River, which generated a massive debris flow (Flores and
Camacho, 1922), however, there is no record of collapses at CP. This might be related to civil protection issues, since the 1920 debris flow completely devastated a community called Barranca Grande (Scott et al., 2001); consequently, little or no attention was given to other areas. On the other hand, we should also consider that propagation of the seismic waves did not impact the $\mathrm{CP}$ in a direct way, and may be associated to structural conditions between the epicenter and the $\mathrm{CP}$ summit.

\section{Conclusions}

From a volcanological perspective, analysis of instability at $\mathrm{CP}$ provides important implications for hazard assessment of extinct volcanoes that are believed to represent relatively safe conditions to nearby populated areas. The results of this study may imply that volcanic structures with a similar setting and evolution might also be unstable, representing a hazard to populated areas located near the path of their main drainage systems and along structurally unstable zones.

We conclude that sector collapse without the presence of a magmatic component is possible, as has been demonstrated in the past by multiple slope failure of the $\mathrm{CP}$ summit area (Carrasco-Núñez et al., 2006), which occurred long after it became extinct. Furthermore, our work provides enough information to show that a weakened volcano can experience sector collapse aided by discrete external triggers such as earthquakes, and favored by extreme climatic conditions even though they did not represent a triggering factor here. Reconstruction of sector collapse shows a strong similarity between proposed scenarios and present topography at CP's summit, suggesting conditions prior to ancient collapses were similar to those present at the actual volcano summit

Finally, it has been determined that a strong $6^{+}$ earth $\neg$ quake in an area near $\mathrm{CP}$ volcano could trigger massive landslides and their most probable path would be towards populated areas along Los Pescados River

\section{Acknowledgments.}

We would like to specially thank CONACYT for grant 44549-F, which financed this project. Dr. Paul Garnica provided useful comments and facilities by the use of the laboratories at the Instituto Mexicano del Transporte (IMT), and Dr. Jaime Horta (Universidad Autónoma de Querétaro, UAQ) and Dr. Lucía Capra made valuable comments on the text. Ms. C. Sara Solís Valdez helped us to edit most of the figures, and José Luis Rodríguez Vargas helped us during the fieldwork. Finally, we would like to thank the Centro de Geociencias, under the direction of Dr. Luca Ferrari, and personnel for their continued support and Sergio Rodríguez and an anonymous reviewer for their final comments on this paper. 


\section{References}

Álvarez-Manilla Aceves, A., Garnica-Anguas, P., Pérez Salazar, A., 2003, Evaluación indirecta de los módulos elásticos de rigidez in situ y la relación entre $\mathrm{Vp} / \mathrm{Vs}$ y el ángulo de fricción interna: Sanfandila, Querétaro, Instituto Mexicano del Transporte, Publicación Técnica $225,39 \mathrm{p}$.

American Society for Testing Materials, ASTM Standard D7012, 2007, Standard test method for compressive strength and elastic moduli of intact rock core specimens under varying states of stress and temperatures, ASTM International, West Conshohocken, PA.

Bieniawski, Z. T., 1973, Engineering classification of jointed rock masses: Transactions of the South African Institution of Civil Engineers $15,335-344$.

Bieniawski, Z. T., 1989, Engineering rock mass classifications: a complete manual for engineers and geologists in mining, civil and petroleum engineering: New York, John Wiley and Sons, $251 \mathrm{p}$.

Cai, M., Kaiser, P. K., Uno, H., Tasaka, Y., Minami, M., 2004, Estimation of rock mass deformation modulus and strength of jointed hard rock masses using the GSI system: International Journal of Rock Mechanics and Mining Sciences, 41, 3-19.

Cai, M., Kaiser, P. K., Tasaka, Y., Minami, M., 2007, Determination of residual strength parameters of jointed rock masses using the GSI system: International Journal of Rock Mechanics and Mining Science, 44, 247-265.

Cantagrel, J. M., Robin, C., 1979, K-Ar dating on eastern Mexican volcanic rocks - relations between the andesitic and alkaline provinces: Journal of Volcanology and Geothermal Research, 5, 99-114.

Carrasco-Núñez, G., Nelson, S., 1998, Edad y tasa de crecimiento del volcán Cofre de Perote (resumen), Primera Reunión Nacional de Ciencias de la Tierra: México D. F., 41.

Carrasco-Núñez, Díaz-Castellón, G., R., Siebert, L., Hubbard, B. E., Sheridan, M. F., Rodríguez-Elizarrarás, S. R., 2006, Multiple edificecollapse events in the Eastern Mexican Volcanic Belt: the role of sloping substrate and implications for hazard assessment: Journal of Volcanology and Geothermal Research, 158, 151-176.

Carrasco-Núñez, G., Siebert, L., Díaz-Castellón, R., Vázquez-Selem, L., Evolution and edifice stability conditions of a compound shieldlike volcano: Cofre de Perote, Eastern Mexican Volcanic Belt (in preparation).

Colindres-Selva, S. R., 1993, Dinámica de suelos y estructuras, 2nd ed.: México D.F., Limusa, 648 p..

Concha-Dimas, A., Cerca, M., Rodríguez, S. R., Watters, R. J., 2005, Geomorphological evidence of the influence of pre-volcanic basement structure on emplacement and deformation of volcanic edifices at the Cofre de Perote-Pico de Orizaba chain and implications for avalanche generation: Geomorphology, 72, 19-39.

Díaz Castellón, R., Hubbard, B., Carrasco-Núñez G., Sheridan, M. F., 2004, Hydrothermal alteration and debris flow/avalanche hazards at Cofre de Perote (México), in IV Reunión Nacional de Ciencias de la Tierra: Juriquilla, Querétaro, Mexico. 145-146.

Díaz-Castellón, R., under revisión, Análisis de la estabilidad estructural del volcán Cofre de Perote: Mexico, Universidad Nacional Autónoma de México, Ph. D. thesis.

Duncan, J. M., 1996, State of the art: Limit equilibrium and finite-element analysis of slopes: Journal of Geotechnical Engineering, 122, 7, 577-596.

Ferriz, H., Mahood, G. A., 1984, Eruption rates and compositional trends at Los Humeros Volcanic Center, Puebla, Mexico: Journal of Geophysical Research, 89, 8511 - 8524.

Flores, T., Camacho, H., 1922, Memoria relativa al terremoto mexicano del 3 de enero de 1920: Boletín del Instituto Geológico de México, $38,107 \mathrm{p}$.

Hoek, E., Brown, E. T., 1997, Practical estimates of rock mass strength: International Journal of Rock Mechanics and Mining Sciences, 34, 1165-1186.

Hoek, E., Carranza-Torres, C., Corkum, B., 2002, Hoek-Brown failure criterion - 2002 edition: Proceedings 5th North American Rock Mechanics Society Symposium and 17th Tunneling Association of
Canada, Toronto, Canada, 1, 267-273

Instituto Nacional de Estadística Geografía e Informática, (INEGI), 1984, Carta topográfica Coatepec E14-B37, 1:50,000 scale: México, D. F., Secretaría de Programación y Presupuesto, Instituto Nacional de Estadística, Geografía e Informática, 1 map.

Instituto Nacional de Estadística Geografía e Informática, (INEGI), 1987a, Carta topográfica Perote E14-B26, 1:50,000 scale: México, D. F., Secretaría de Programación y Presupuesto, Instituto Nacional de Estadística, Geografía e Informática, 1 map.

Instituto Nacional de Estadística Geografía e Informática, (INEGI), 1987b, Carta topográfica Xalapa E14-B27, 1:50,000 scale: México, D. F., Secretaría de Programación y Presupuesto, Instituto Nacional de Estadística, Geografía e Informática, 1 map.

Instituto Nacional de Estadística Geografía e Informática, (INEGI), 1990, Carta topográfica Xico E14-B36, 1:50,000 scale: México, D. F., Secretaría de Programación y Presupuesto, Instituto Nacional de Estadística, Geografía e Informática, 1 map.

Lagmay, A. M. F., van Wyk de Vries, B., Kerle, N., 2000, Volcano in $\neg$ stability induced by strike-slip faulting: Bulletin of Volcanology, 62, 331-346.

López, D. L., Williams, S. N., 1993, Catastrophic volcanic collapse: relation to hydrothermal processes: Science, 260, 1794 - 1796.

Merle, O., Borgia, A., 1996, Scaled experiments of volcano spreading: Journal of Geophysical Research, 101, 13805 - 13817.

Mossman, R. W., Viniegra, F., 1976, Complex fault structures in Veracruz Province of Mexico: American Association of Petroleum Geologists Bulletin, 60, 379-388.

Mualchin, L., 1996, A technical report to accompany the Caltrans California seismic hazard map 1996 (based on maximum credible earthquakes): Sacramento, California, Department of Transportation, $65 \mathrm{p}$.

Nakamura, K., 1977, Volcanoes as possible indicators of tectonic stress orientation - Principle and proposal: Journal of Volcanology and Geothermal Research, 2, 1 -16.

Rocscience Inc. 2003, Slide Version 5.0-2D Limit equilibrium slope stability analysis: Toronto, Ontario, Canada, http://www.rocscience. com.

Scott, K. M., Macías, J. L., Naranjo, J. A., Rodriguez, S., McGeehin, J. P., 2001, Catastrophic debris flows transformed from landslides in volcanic and tropical terrains: mobility, hazard assessment, and mitigation strategies: U.S. Geological Survey Professional Paper $1630,59 \mathrm{p}$.

Siebert, L., Glicken, H., Ui, T., 1987, Volcanic hazards from Bezymiannyand Bandai-type eruptions: Bulletin of Volcanology, 49, 435-459.

Suarez, G., 1992. El sismo de Jalapa del 3 de enero de 1920: Revista Mexicana de Ingeniería Sismica, 42, 3-15.

Tibaldi, A., Corazzato, C., Apuani, T., Cancelli, A., 2002, Deformation at Stromboli volcano (Italy) revealed by rock mechanics and structural geology: Tectonophysics, 361, 187-204.

van Wyk de Vries, B., Borgia, A., 1996, The role of basement in volcano deformation, in McGuire, W. J., Jones, A. P., Neuberg, J. (eds.) Volcano instability on the Earth and other planets: Geological Society, London, Special Publications, 110, 95-110.

Watters, R. J., Delahaut, W. D., 1995, The effect of argillic alteration on rock mass stability: Geological Society of America Reviews in Engineering Geology, X, 139-150.

Watters, R. J., Zimbelman, D. R., Bowman, S. D., Crowley, J. K., 2000, Rock mass strength assessment and significance to edifice stability, Mount Rainier and Mount Hood, Cascade Range volcanoes: Pure and Applied Geophysics, 157, 957-976.

Yañez García, C., García Durán, S., 1982, Exploración de la región geotérmica de Los Humeros-Las Derrumbadas, estados de Puebla y Veracruz: México D. F., Comisión Federal de Electricidad, Technical report, $96 \mathrm{p}$.

Yu, H. S., Salgado, R., Sloan, S. W., Kim, J. M., 1998, Limit analysis versus limit equilibrium for slope stability: Journal of Geotechnical and Geoenvironmental Engineering, 124, 1, 1-11.

Manuscript received: February 6, 2008;

Corrected manuscript received: June 15, 2008;

Manuspcrit accepted: June 26, 2008. 